\title{
Evtushenko and the Underground Poets ${ }^{1}$
}

\section{he more one studies the Symbolist-Acmeist-Futurist creative explo- 1 sion in Russian poetry of the first three decades of our century, the}

more staggered one is by its total scope and accomplishment. By the early 1930s, that great age was forcibly brought to an end by what in retrospect amounts to a governmental ban on all creativity and imagination. While Mayakovsky was being acclaimed the great Soviet poet and his work nationalized, while Pasternak was being decried by the Soviet press for his uniqueness and individuality, no younger poet was any longer allowed to try to equal the stylistic daring and modernity of either of these two. Victorian-age poetic techniques, themes, and styles were brought back, proclaimed the latest word, and institutionalized as the only possible way for Socialist-Realist poetry, whereupon all Russian poetry worthy of the name ceased until after Stalin's death. As Boris Slutsky, a poet who survived the Stalinist period, described the plight of Russian poetry during those years:

Only yesterday she was on the run,

Wringing her hands in terror.

Only yesterday she was on the executioner's block

For perhaps the tenth time.

1 Review of Antiworlds: Poetry by Andrei Voznesensky, ed. Patricia Blake and Max Hayward (New York: Basic Books, 1966); The New Russian Poets, 1953-1966: An Anthology, ed. and trans. George Reavey (New York: October House, 1966); Yevtushenko Poems, trans. Herbert Marshall (New York: E. P. Dutton, 1966); Voznesensky: Selected Poems, trans. Herbert Marshall (New York: Hill and Wang, 1966); Selected Poems of Andrei Voznesensky, trans. Anselm Hollo (New York: Grove Press, 1964); Selections from "The Bratsk Hydroelectric Station" and Other Poems, by Yevgeny Yevtushenko, trans. Bernard L. Koten (New York: New World Review, 1965); Stikhotvoreniia $i$ poemy [Selected poetry], by Iosif Brodskii (Washington, D.C.: Inter-Language Literary Associates, 1965); poems by Nikolai Morshen, in Novyi zhurnal, nos. 82 and 83 (1966); Bulat Okudzhava Sings His Songs, 12-inch record, recorded and pressed for ARFA by RCA Victor Custom Records Division; and "Lots of Luck, Kid!," by Bulat Okudzhava, trans. Robert Szulkin, in Pages from Tarusa, ed. Andrew Field (Boston: Little, Brown, 1964). Originally published in Nation, 21 November 1966, 549-53. 
Since 1956, however, there has been a definite poetic revival in the Soviet Union. ${ }^{2}$ Within the country, the most striking development of the past decade is the grudging recognition now granted to the great Russian poets of the early twentieth century and, most important, the partial availability of their work. The recognition and availability are limited and subject to certain carefully observed ideological rules, but with all that, the really momentous phenomenon in Russian poetry of the past ten years is that the poems of Anna Akhmatova, Boris Pasternak, Marina Tsvetaeva, Velimir Khlebnikov, Nikolai Zabolotsky and, most recently, Andrei Bely can actually be read, after decades of suppression, vilification, and officially imposed oblivion. But at least a dozen other major poets who were exiled, condemned to silence, or physically destroyed by the Soviet regime (Kuzmin, Gumilyov, Mandelstam, Zinaida Gippius, Vyacheslav Ivanov, and Khodasevich, to name a few) have not yet been republished and are still treated very gingerly in the Soviet press and scholarship.

Outside the Soviet Union, the younger post-Stalinist poets have been making the biggest news. The international attention now attracted by Evtushenko and Voznesensky is nothing short of phenomenal. Their poetry is read in translation and acclaimed by thousands of young Europeans and Americans for whom Akhmatova and Pasternak were merely names, and who have probably never heard of Mandelstam or Tsvetaeva or Zabolotsky. This situation is paradoxical: the reverse would be if a generation of Russian readers who had never heard of Yeats or T. S. Eliot or Auden or Marianne Moore were suddenly to acclaim Allen Ginsberg as the first significant English-language poet since Whitman and Wilde. But this situation is also a sign of the times. The fact is that Evtushenko and Voznesensky represent two of the possible options that a Russian poet has today. Examining the respective situations and accomplishments of these poets and contrasting them to the alternative options, exemplified by such poets as Bulat Okudzhava, Joseph Brodsky, and Nikolai Morshen, may perhaps throw light on the actual state of Russian poetry.

Evgeny Evtushenko is undoubtedly the biggest name in Soviet poetry today. There has not been such a matinee idol in Russian poetry since

2 Once again the reader is reminded that SK is addressing a particular moment in time (here the 1960s in the history of Russian poetry) and will encounter a high number of time-specific references.-Ed. 
the days when Igor Severyanin used to recite his Ego-Futuristic poems to audiences on the eve of World War I. Despite Evtushenko's vehement denials, there is an unmistakable kinship: he shares Severyanin's penchant for a pseudoelegant foreign vocabulary and has on occasion the same surefire sentimentality and the same facile and bouncy optimism. He also possesses Severyanin's theatrical flair. To hear Evtushenko recite his versified editorials is a spellbinding experience, but deprived of the author's delivery and reduced to a printed page, his poems inevitably disappoint.

Evtushenko's main strength is in being topical. Such poems as Babi Yar, "The Ballad on Poaching," the still-unpublished "Letter to Esenin" and the recent, dreadfully maudlin "Italian Tears" can state the thoughts and attitudes of the younger Soviet generation in ways that could not be safely printed in the Soviet Union unless dressed up as verse. There is an obvious analogy in this with the tsarist Russia of the 1860s: Nekrasov's verse and Chernyshevsky's literary criticism also had ways of bringing up certain "burning issues" otherwise too hot to be aired publicly. Considering the role his poetry plays within present-day Soviet society, Evtushehko's success and fame at home are both understandable and well deserved. But when his foreign admirers accept his mixture of grandstand histrionics and mawkish sentiment as a major poetic utterance of our age, there is evidence of a total misunderstanding of what poetry is all about. ${ }^{3}$

3 One of SK's first published reviews-of Vzmakh ruki (Moscow: Molodaia gvardiia, 1962), by Evtushenko, in Books Abroad 37 (Summer 1962): 355-contains a succinct summary of the popular young poet's impact.—Ed.:

Evtushenko is predominantly a civic poet. As such, he voices, in versified editorials and within certain prescribed limits, the aspirations of the Soviet younger generation.

Abroad, his poems are often read as a sort of political barometer. Both at home and abroad his popularity seems to be due to extraliterary reasons. His more orthodox pieces, such as the protestations of fealty to the Revolution or the odes in honor of Fidel Castro, are not very different from the sort of thing Soviet poets wrote under Stalin, except possibly for the "Evtushenko rhyme." (The method of rhyming in which the first rather than the last syllable of the final word in a line is rhymed, with an assonance in the stressed syllable where the rhymed syllable is unstressed, was introduced in Russian poetry at the turn of the century, evidently by Zinaida Gippius, and was later used by Gumilyov in "Zavodi." It is at present very popular with the younger poets and Evtushenko is usually credited with having invented it.) ...

For all that, the sheer fact of Evtushenko's popularity may yet lead to new and salutary developments in Russian poetry. Despite the orthodox tone of 
Evtushenko can be admired for his editorial daring. The daring of Andrei Voznesensky is largely stylistic and thematic. His poetry tries to be frankly original and unabashedly imaginative-two qualities that are of course essential for any true poetry, but which were considered grave sins in Stalin's era. Voznesensky, more than any other young Soviet poet, also brings back the emphasis on the verbal aspects of the poet's craft. His strident assonances, out-of-control alliteration, and overly insistent play on verbal stems are all borrowed from his great predecessors Khlebnikov, Pasternak, and Marina Tsvetaeva; however, they used such devices both with more restraint and with greater expressive effect. But these poets are dead, while Andrei Voznesensky is alive and celebrated and, besides, Soviet poetry can certainly use a transfusion of technical originality, whatever the source. A far more talented and accomplished poet than Evtushenko, Voznesensky shares with him a certain provincial limitation of outlook and the habit of interspersing his more daring efforts with more conventional or even conformist utterances on the standard themes of official Soviet poetry: the greatness of the Russian people, the tenderness and affection inspired in the poet by Lenin's name, and the horrors of American militarism, Western decadence, and the FBI. When Mayakovsky treated similar themes back in the 1920s, there was no doubt that they represented his actual convictions; in Evtushenko and Voznesensky, whatever their feelings may be, the reader gets the inevitable clichés which all Soviet writers (and especially those allowed to travel abroad) have been required to reiterate ad nauseam for the past thirty years.

For the third most popular Russian poet now writing, Bulat Okudzhava, freedom from the compulsory cliché has become the crucial freedom within the context of Soviet literature. Although he has published several slim volumes of verse, Okudzhava is primarily a chansonnier in the French tradition. The effect of his poems depends equally on the melodies he composes for them and on his own subdued and intimate delivery. The

much of what he has to say, he does make a conscious effort to bring Russian verse back into the twentieth century from the limbo of the Soviet neo-Victorianism to which it was relegated under Stalin. Above all, there is in his work an open concern for problems of technique and versification. In the work of Evtushenko's more talented contemporaries (Voznesensky, Akhmadulina, Novella Matveeva), his example has already led to some fresh and promising poetic departures. 
most original and popular of his songs were not included in his published collections, nor are they commercially available on Soviet-made records, but privately made tapes of Okudzhava's songs enjoy an enormous circulation in the Soviet Union, and no party in Moscow or Leningrad has been complete without them for the past five years. The recording recently released in this country contains some of his best-known pieces. A good half of the songs included represent underground poetry.

The concept of literature, including poetry, as a lesson or a sermon has always been central to Soviet culture. In his minor and modest way, Okudzhava now revives the opposite, nondidactic concept of art, stemming in the Russian tradition from Pushkin and Chekhov. His songs simply show or describe things as he sees them, and his attitude to his subject matter is contained within his manner. He can also be quite refreshingly irreverent. His "Paper Soldier" treats the whole notion of military heroics, Soviet or otherwise, as absurd (the same kind of scoffing in Okudzhava's amusing novella Lots of Luck, Kid! was literally horrifying to the orthodox Soviet critics).

Another Okudzhava song tells of waterfront prostitutes and of some Soviet sailors who are frightened to go out to sea. Prostitution is not indicted, the sailors' cowardice is neither defended nor condemned-there is an implied presupposition of an adult audience that has outgrown Sunday school. Okudzhava's “The Midnight Trolley" has particularly irked those who uphold the orthodox Soviet mentality. The hero of this song tells of his remedy against loneliness and acute depression: take the midnight trolley in Moscow and sit in it next to others who have also experienced shipwreck in the night. Neither Lenin nor the great Russian people are evoked. Instead:

Who would have thought that there is so much kindness In silence. In silence.

Quietly, unobtrusively, Okudzhava brings back the things that are most inimical to the Soviet brand of Socialist-Realist aesthetics, a detached irony, freedom to be either optimistic or pessimistic, depending on the subject at hand, and at times a genuine sense of human tragedy. His refusal to take out insurance in the form of occasional repetition of official clichés is apparently what makes some of his most popular work 
unpublishable in the Soviet Union to this day. Other younger Soviet poets who have come into prominence in the past decade-Bella Akhmadulina, Evgeny Vinokurov, Viktor Bokov, Novella Matveeva-do take out such insurance. The remaining alternatives for a Russian poet today are to publish clandestinely in the Soviet Union (and perhaps to send work to be published abroad at great personal risk) or to be an émigré poet.

Shortly before her death, Anna Akhmatova stated in several interviews that today's important and lasting Russian poetry does not appear in the official press and is unknown abroad. ${ }^{4}$ The underground poetry Akhmatova had in mind has a minuscule circulation in the Soviet Union in mimeographed publications, the very names of which constitute a challenge to what is officially acceptable: Syntax (an open invitation to a charge of Formalism), Sphynxes (an assertion of the mystery of poetic creation) and Phoenix (a rebirth of poetry from the ashes). In these privately circulated publications (some of which have been reprinted in toto in a West German émigré journal), young and unknown poets can achieve a full measure of freedom from ideological fetters and can write in any style about anything they please. Their stylistic inspiration comes for the most part from Khlebnikov's experiments with language of some fifty years ago; Marina Tsvetaeva (who committed suicide in 1941 after her voluntary return from exile) and Nikolai Gumilyov (shot for counterrevolutionary activities in 1921) are here objects of a cult. The poetry in these little journals is by no means great, and it is rarely even good, but it is fresh and free in a way Evtushenko's is not.

The most notable poet to have so far emerged from these clandestine publications is Joseph Brodsky, who became famous after the Soviet authorities put him on trial for being a "parasite" and a "sponger." The transcript of his trial, published in the West, left no doubt that what was really indicted in Brodsky's person was the whole notion of writing socially useless poetry. After being sentenced to five years at hard labor, and spending almost two years carting manure in a remote northern area, Brodsky was quietly released this year. A piece of poetry he has written since his release has just reached the West; it is a cycle of poems dedicated to the memory of T. S. Eliot. A selection of Brodsky's poems,

4 See Alexander Werth, “Akhmatova: Tragic Queen Anna," Nation, 22 August 1966, 157-60. 
most of which appeared in Soviet underground journals, was published in 1965 by the Inter-Language Literary Associates of Washington, D.C. Brodsky's poetry is uneven, and often murky and verbose, but at its best it has a seriousness and a profundity no other Soviet poet can match. He uses surrealistic imagery freely; his acknowledged foreign influences-John Donne and Eliot—are not on any Soviet-approved list; and if Okudzhava's jaunty songs admit only a possibility of a tragic view of life, Brodsky's brooding elegies are at times permeated with an oppressive sense of doom which only the eternal values of art and nature are allowed to overcome.

The best present-day Russian poetry is not produced by any of the four by-now internationally famous poets discussed so far. Since the death of Anna Akhmatova, the finest living Russian poet is a man whose poetry is known to perhaps a few hundred people at most. His name is Nikolai Morshen. In originality of content, profundity, literary culture, and craftsmanship, neither Voznesensky nor Brodsky can even touch his work. Morshen has been publishing for over a decade, yet his name remains virtually unknown in the Soviet Union. It is all a question of the peculiar role of geography in modern Russian literature. Saint-John Perse or Thomas Mann could reside in America and maintain their positions in their respective literatures, but a modern Russian writer who leaves his country inevitably loses not only his Russian audience but any claim to international attention.

Nikolai Morshen, the most important of several interesting Russian émigré poets now active in the West, left Russia as a very young man during World War II and lives at present in Monterey, California. His one small book of verse was published in West Germany in 1959. Entitled The Seal, the book uses this pinniped mammal, with its breathing hole in the Arctic ice, as the central metaphor for the collection, whose theme is the situation of a restless and inquisitive intellectual in an environment of totalitarian orthodoxy. Since the publication of The Seal, Morshen's poetry has been steadily growing in scope and stature. This year he has published in the New York-based Russian literary journal Novyi zhurnal two sets of poems which clearly place him in the front rank of twentiethcentury Russian poets. Influenced initially by Mandelstam, Pasternak, and Zabolotsky, and later by Teilhard de Chardin, Morshen has more recently matured into a wholly original poet, unlike any other in Rus- 
sian literature. His latest poetry draws on completely new areas of human thought (cybernetics and paleontology, for example); the elegance of his verbal texture, which is light years away from the strident pyrotechnics of a Voznesensky, is comparable to the best of Pasternak. A recent poem in which the grasses and weeds of the North American wilderness are made to recite a tiny anthology of classical Russian poetry is a tour de force of truly dazzling proportions. There is no doubt that a large and enthusiastic audience awaits Morshen's poetry in the Soviet Union, should it be made available there (at which time, presumably, translators into other languages will also deign to notice it). ${ }^{5}$

In the meantime, there is a veritable flood of English translations of Evtushenko and Voznesensky. Anselm Hollo's versions of Voznesensky, inexplicably endorsed by the poet himself and now available in paperback, are a particularly blatant example of that all-too-frequent recent phenomenon of translation of Russian literature by guesswork. Knowing the language only sketchily and apparently not wishing to use a dictionary, Hollo translates "hunting hound" as "rodent"; "Ah, those home-grown Iagos!" as "O they are hothouse flowers"; and "Poetesses hasten to become market-women" (Poetessy begut v lotoshnitsy) as "And the poet-girls, running, running ... / Toward the trembling black grove." Whenever the text gets too idiomatic for comfort, Hollo simply drops the passage and develops an earlier or later phrase. He throws in Anglo-Saxon obscenities or French words, apparently just for the hell of it, when there is not the slightest pretext for them in Voznesensky's Russian original. At times he totally misses the point of an entire poem.

Compared to Hollo's “translations," even Herbert Marshall's versions of Evtushenko and Voznesensky look good. But the improvement is only relative. Marshall understands many more Russian words, and he tries to convey something of Voznesensky's style and verbal structure. But as an English stylist, Marshall is naive, to say the least, and he, too, has considerable difficulties with the Russian idiom. Voznesensky's introduction to his "Triangular Pear" begins, "I am writing a work of major proportions, with a plot. It is about 'the discovery of America." Marshall's rendition of this is "I am working on a big thematic subject 'About the Discovery

5 Morshen's development as a poet remained of particular interest to SK. See the two later essays on Morshen (published in 1982 and 1993) in the present volume._Ed. 
of America." (Hollo's version of the passage is "I am working on a great theme: the discovery of America.")

Marshall's own wildly ungrammatical Russian sentences, quoted by him in his largely irrelevant introduction to the Voznesensky volume, leave no doubt how ill-equipped he is to translate anything at all from that language. Copious footnotes have been supplied by Marshall for both the Evtushenko and the Voznesensky volumes, and the only word for some of them is "unbelievable." Natasha Rostova, in a footnote appended to a spectacularly garbled and misunderstood Evtushenko passage, is described as a character from Tolstoi's "great novel Anna Karenina," 6 wile the Queen of Sheba and Bathsheba, mentioned in Voznesensky's "Ballad of Work," are left in their Russian transcriptions and helpfully identified by Marshall as "a Tsarina of Russia, patron of the arts, of whom many portraits were painted," and "a lake in Estonia," respectively.

Fragments from Evtushenko's long epic The Bratsk Hydroelectric Station have been translated by Bernard L. Koten. (How odd that this sprawling, verbose opus should become available in some three English translations, while such authentic masterpieces of Russian twentieth-century narrative poetry as Bely's The First Rendezvous, Tsvetaeva's Poem of the End, and Zabolotsky's Triumph of Agriculture, to name a few, still remain untranslated.) Koten worked with greater care than Marshall, in whose volume this poem is also partly represented. At least Koten conveys the meaning of the title, while Marshall's equivalent, "Bratsky GES," makes no sense in English and throws the gender agreement of Evtushenko's Russian title out of kilter. But Koten, alas, also has his vocabulary trouble (Evtushenko speaks of Lermontov's "bilious gaze," which Koten renders as "bitter vision"), and as poetry, even on Evtushenko's level of the term, Koten's translation is often plodding and uninspired.

The same has to be said, unfortunately, of the translations in George Reavey's anthology, though they are on a far superior level than the grotesqueries of Hollo or Marshall. In addition to the inevitable Evtushenko, Reavey's book offers a sampling of Voznesensky, Brodsky, Okudzhava, the underground poet Galanskov, the witty and whimsical Novella Matveeva

6 Yevtushenko Poems, 149.

7 Voznesensky: Selected Poems, 115. SK was to subject the translator to further scathing scrutiny a year later in his review of Mayakovsky, trans. and ed. Herbert Marshall (New York: Hill and Wang, 1965), in Russian Review 26, no. 4 (October 1967): 413-15._Ed. 
(her least typical work, it seems), and a few others, but all of them somehow emerge flat and unrewarding in English, with Okudzhava, stripped of his direct and laconic manner and relentlessly explicated to the full, faring about the worst. Whatever one can say about the new post-Stalinist Soviet poets, one thing is certain: they deserve better from their English translators.

Voznesensky, for one, does get better (and then some) in the unusual volume Antiworlds, edited by Patricia Blake and Max Hayward. The contrast between this volume and the others mentioned is dazzling. Not only have Voznesensky's poems been translated by those who have understood all his Russian words and who have no problems with Russian idiom or syntax (an elementary requirement, of course, though it is rarely met these days), but most of the poems in this volume stand up remarkably well as English poetry. In fact, the paradoxical fault of Antiworlds, if regarded as a set of translations, is that the results are too spectacularly good. Put into English by the likes of W. H. Auden, Robert Lowell (who on this occasion, for once, was given reliable trots), and Richard Wilbur, Voznesensky loses the naive and provincial tone he often has in Russian, sheds his often crude and overemphatic alliteration, and indeed becomes the kind of poet he undoubtedly could be had he the literary culture and sophistication of his translators. But this is probably mere carping. Everybody who contributed to Antiworlds is to be congratulated (Voznesensky on his good fortune). Is it too much to hope that a similar venture may be organized by the editors to furnish an equally successful English volume of Mandelstam or Tsvetaeva or Khodasevich or Zabolotsky?

As SK remarks in the essay above, Joseph Brodsky was surely the most considerable figure in Russian poetry to emerge in the post-Stalin era. Regrettably, SK never wrote at length on Brodsky, and his only other recorded statement about him — so far as is known to the present editors-is contained in an answer (apparently never published) to a questionnaire about the poet solicited from SK in early February 1980. He chose to reply only to the second of five questions: "What features of Brodsky's poetry are particularly valuable for you?" His response follows. 
My first contact with the poetry of Joseph Brodsky was through a tape recording made by Clarence Brown in Leningrad of a reading by Brodsky of his poems dedicated to the memory of T. S. Eliot. The originality of Brodsky's poems was striking, and striking, too, was the manner of reading, which went against their metrics: a mixture of the ComédieFrançaise and a Jewish cantor.

For me the most memorable reading aloud of Brodsky's verse was in the kitchen of a friend of mine in San Francisco: against a background of a pile of dirty dishes and wine glasses, Mikhail Baryshnikov was fervently declaiming: И если что-нибудь взлетало в воздух,
то был не мост, то Павлова была

(And if anything took flight into air, it was no bridge, it was Pavlova).

No personal encounter ever actually took place. There was once a reception at my home in his honor. The house was full of noisy people, most of them unknown to me. Brodsky was besieged by Berkeley students wanting to know why he left the progressive Soviet Union for the citadel of imperialism. He had a toothache, and had little patience with them. Right there beside him were Russians, recently arrived in America, who were instructing other Russians (who had lived in America for decades) how one was to behave here and generally just what's what. Some sort of scandal out of Dostoevsky's Possessed was brewing, though it never actually erupted. Someone burned the table with a cigarette. Someone, attempting to leave, couldn't manage the front door and broke the lock (a locksmith had to be called). And left behind, a woman's knitted jacket of gigantic proportions was hanging long afterward in the entryway. It was eventually donated to a charitable organization with other rubbish.

Any real encounter with Brodsky occurs in the poems he began writing a couple of years after that evening. They appeared first in the Messenger of the Russian Christian Movement (Vestnik Russkogo khristianskogo dvizheniia) and later in the elegant gray volumes published by Ardis, The End of a Beautiful Epoch (Konets prekrasnoi epokhi) and A Part of Speech (Chast' rechi). Brodsky as poet had matured to the point of being unrecognizable in them. Twenty Sonnets to Maria 
Stuart (Dvadtsat' sonetov k Marii Stiuart), "Mexican Divertimento" ("Meksikanskii divertisment"), "Classical Ballet" ("Klassicheskii balet") sum up the epoch of Akhmatova and Mandelstam, the way the young Pushkin subsumed everything that had been done in Russian poetry before him and then advanced beyond.

Voices that were heard even earlier in Joseph Brodsky's poetrythose of the Englishmen John Donne, William Blake, and T. S. Eliotare still heard in it. Above all, his own can be heard in it, inimitable and absorbing.

Comparing poets who are contemporaries with each other odiosa sunt. But one can hardly doubt that, of all the Russian poets who have appeared in the second half of the present century, Brodsky is the most outstanding. And, as Mirsky once wrote about Tsvetaeva, it is pleasant to sense that you live at the same time as Brodsky. ${ }^{8}$

8 Translated from the Russian from the original document in carton no. 7, Simon Karlinsky Papers, BANC MSS 2010/177, The Bancroft Library, University of California, Berkeley. Correspondence between SK and Gregory Poliak, editor-publisher of Silver Age Publishing, indicates that a section of a volume to be published to mark the $40^{\text {th }}$ birthday of Joseph Brodsky was to be devoted to responses to a questionnaire also to be sent to Mikhail Baryshnikov, John Updike, Mstislav Rostropovich, Andrei Sinyavsky, Nina Berberova, Susan Sontag, and others. In the event, they were not published in the volume, Chast' rechi: Al'manakh literatury i iskusstva, no. 1 (New York: Serebrianyi vek, 1980). 